\title{
A Case of Furuncular Myiasis Due to Cordylobia anthropophaga in a Korean Traveler Returning from Uganda
}

\author{
Su-Min Song ${ }^{1,3}$, Shin-Woo Kim², Youn-Kyoung Goo', Yeonchul Hong', Meesun Ock ${ }^{3}$, Hee-Jae Cha, ${ }^{3, *}$ \\ Dong-II Chung, ${ }^{1, *}$ \\ 'Department of Parasitology and Tropical Medicine, ${ }^{2}$ Department of Internal Medicine, School of Medicine, Kyungpook National University, Daegu \\ 41944, South Korea; ${ }^{3}$ Department of Parasitology and Genetics, Kosin University College of Medicine, Busan 49267, Korea
}

\begin{abstract}
A fly larva was recovered from a boil-like lesion on the left leg of a 33-year-old male on 21 November 2016 . He has worked in an endemic area of myiasis, Uganda, for 8 months and returned to Korea on 11 November 2016. The larva was identified as Cordylobia anthropophaga by morphological features, including the body shape, size, anterior end, posterior spiracles, and pattern of spines on the body. Subsequent $28 \mathrm{~S}$ rRNA gene sequencing showed $99.9 \%$ similarity (916/917 bp) with the partial 28S rRNA gene of $C$. anthropophaga. This is the first imported case of furuncular myiasis caused by $C$. anthropophaga in a Korean overseas traveler.
\end{abstract}

Key words: Cordylobia anthropophaga, myiasis, furuncular myiasis, molecular identification, 28S rRNA gene, Korean traveler

\section{INTRODUCTION}

Myiasis is a parasitic infestation by larval stages of the flies in the tissues of humans and animals. It is widespread in tropical and subtropical areas, including Central America, South America, and tropical Africa [1]. It is classified based on the infestation site, e.g., cutaneous, oral, ocular, nasal, and urogenital. The cutaneous myiasis is the most frequent and impressive form, and it can be divided into 3 types by clinical features and type of larvae: furuncular, migratory, and wound myiasis [2].

Furuncular myiasis is defined as the penetration of the larvae inside the healthy skin and development of a boil-like nodule. It is more common in tropical countries and can be caused by the human botfly Dermatobia hominis in Latin America, the tumbu fly Cordylobia anthropophaga, and the Lund's fly Cordylobia rodhaini in Africa [3,4].

The tumbu fly, C. anthropophaga, is a blowfly belonging to the family Calliphoridae and one of the most prevalent agents

\footnotetext{
- Received 9 February 2017, revised 15 March 2017, accepted 2 April 2017.

*Corresponding authors (hcha@kosin.ac.kr; dichung@knu.ac.kr)

(C) 2017, Korean Society for Parasitology and Tropical Medicine

This is an Open Access article distributed under the terms of the Creative Commons Attribution Non-Commercial License (http://creativecommons.org/licenses/by-nc/4.0) which permits unrestricted non-commercial use, distribution, and reproduction in any medium, provided the original work is properly cited.
}

throughout the tropical and subtropical Africa [5]. Humans can be infested through direct exposure to environments contaminated with eggs of the fly [6].

In this study, we present the first case of furuncular myiasis in a Korean traveler returning from Uganda. The larva was removed from a boil-like lesion of the patient's leg and identified as C. anthropophaga from both morphology and nucleotide sequence analysis of the $28 \mathrm{~S}$ rRNA gene.

\section{CASE RECORD}

A 33-year-old male was transferred to the emergency room of Kyungpook National University Hospital from a local dermatology clinic on 21 November 2016. He had worked in Uganda for 8 months and returned to Korea on 11 November 2016. He found that 2 boil-like lesions with a small central punctum appeared on his left leg and developed as an abscess (Fig. 1). A third instar larva was removed from one of the lesions at the local dermatology clinic. In order to treat of secondary bacterial skin infection, antibiotics, ampicillin, and sulbactam (750 mg, 3 times/day), was given orally for 7 days by an infectious disease physician.

The larva was $6 \times 2.9 \mathrm{~mm}$ in size, yellowish color with cylindrical body, and had 11 segments. The segments III-VIII had numerous small black, scattered spines, while IX-XI were al- 
most bare (Fig. 2). The anterior end had 2 black mouth-hooks with curved and sharp tips without cluster of conic denticles

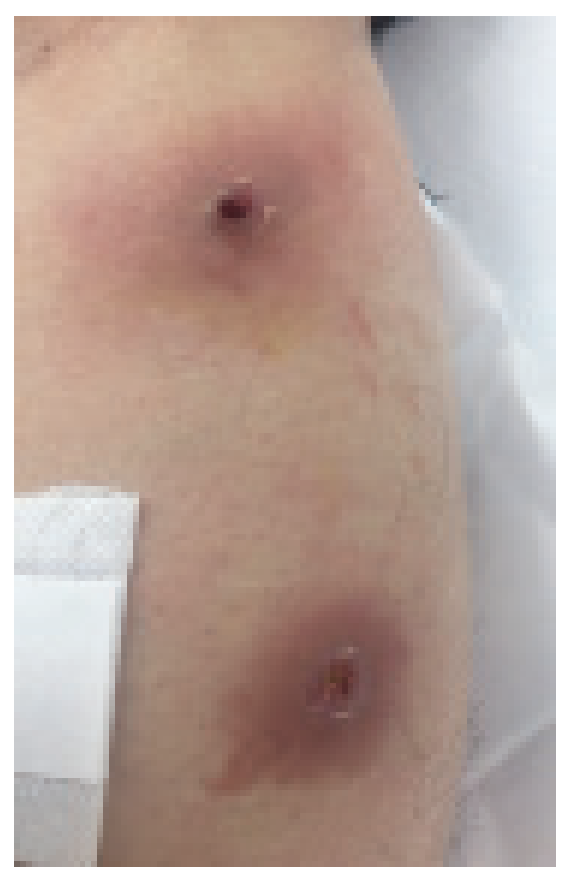

Fig. 1. Boil-like lesions caused by Cordylobia anthropophaga on the left leg of the patient.
(Fig. 3). Fig. 4 shows the posterior spiracle of the larva, the spiracles carried 3 curved spiracular openings without peritreme. These morphological characteristics were consistent with those described for C. anthropophaga [7].

For genetic analysis, total genomic DNA was extracted from the larva with QIAamp DNA Mini kit (Qiagen, Hilden, Germany) according to the manufacturer's instructions. The primers for nested PCR designed by Ruan et al. [8], which amplify 28S rRNA gene (Forward-1: 5'- GGGAGGAAAAGAAACTAACAAGGA-3', Reverse-1: 5' - CTGTTTCGGTCTTCCATCAGGG-3', Forward-2: 5' - CTTAGTAGCGGCGAGCGAAAA-3', Reverse-2: 5' - TTCCCCT-GACTTCAACCTGATC-3'). PCR was performed as follows: initial denaturation at $94^{\circ} \mathrm{C}$ for $5 \mathrm{~min}$, followed by 30 cycles of denaturation at $94^{\circ} \mathrm{C}$ for $30 \mathrm{sec}$, annealing at $60^{\circ} \mathrm{C}$ for $30 \mathrm{sec}$ and extension at $72^{\circ} \mathrm{C}$ for $2 \mathrm{~min}$, and a final extension at $72^{\circ} \mathrm{C}$ for $5 \mathrm{~min}$. The PCR product was 916 bp, bi-directionally sequenced, and identified using BLAST (Basic Local Alignment Search Tool) analysis. The sequences showed $99.9 \%$ similarities with the partial of 28S rRNA gene of C. anthropophaga 'isolate Yaounde' from Cameroon (GenBank no. AJ551432) and 'isolate Zhejiand from Uganda (GenBank no. KM506761) and 98.1\% with 'isolate B25' from Namibia (GenBank no. JQ246627). Phylogenetic analysis re-

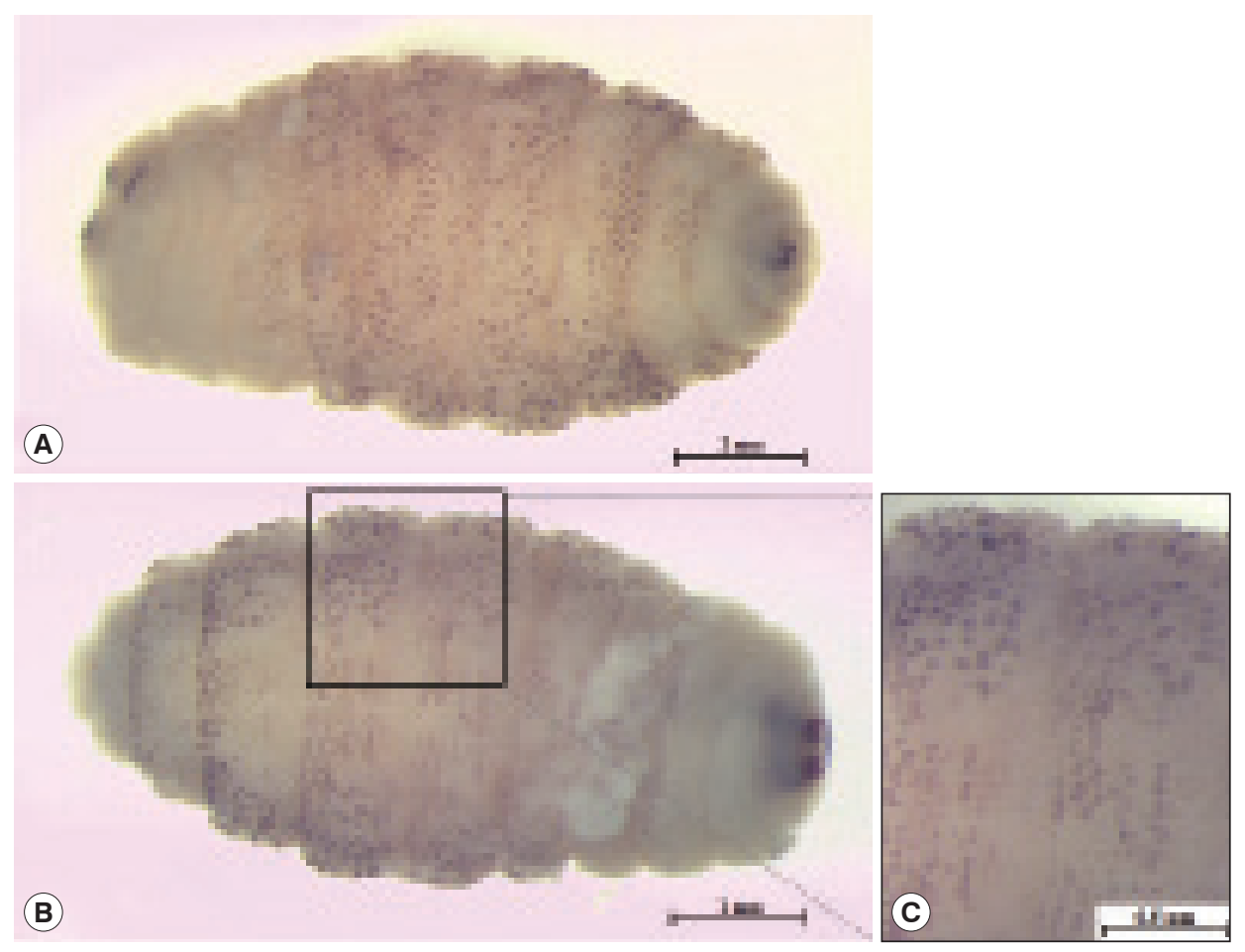

Fig. 2. Third instar of $C$. anthropophaga removed from the lesion. (A) Ventral side of the body. (B) Dorsal side of the body. (C) Spines on the body. 

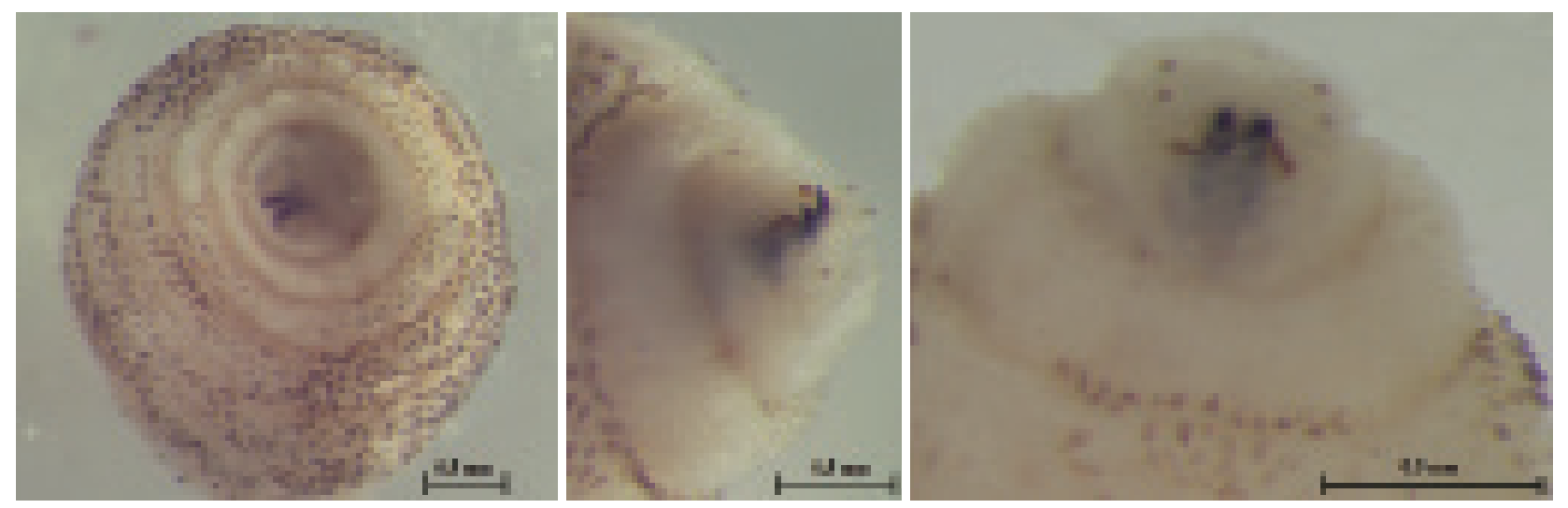

Fig. 3. Anterior end of $C$. anthropophaga showing 2 black mouth-hooks.
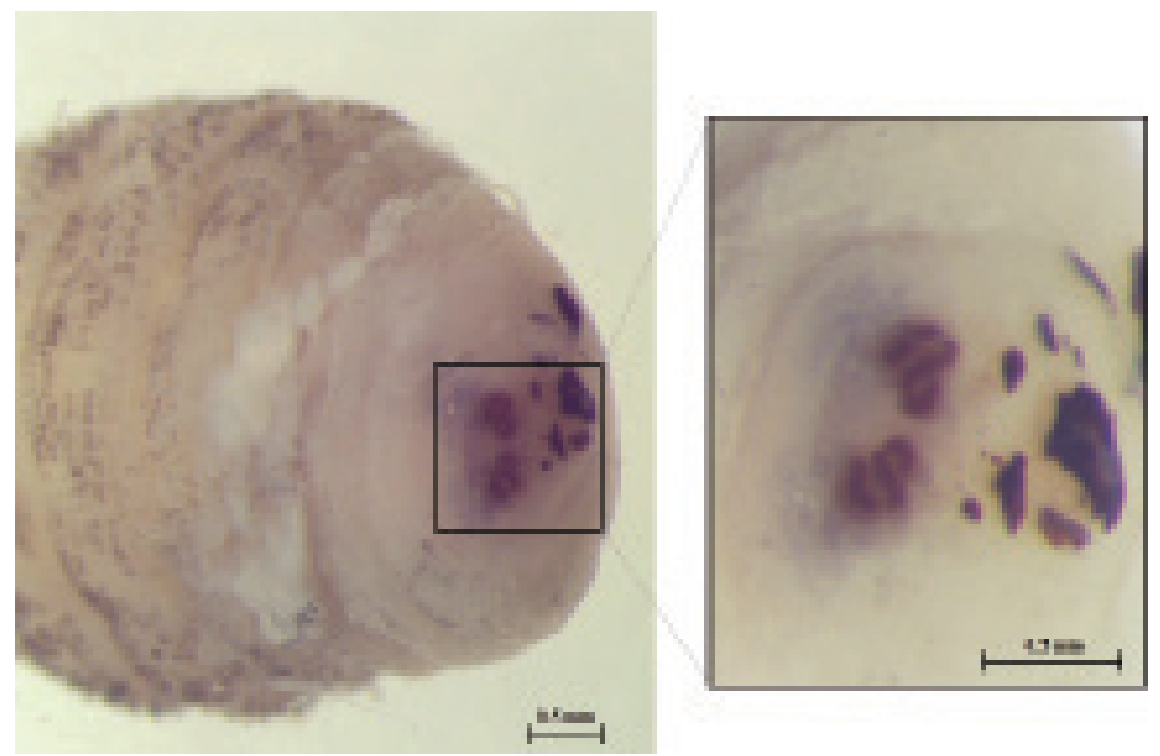

Fig. 4. Posterior spiracles carrying 3 sinuous spiracular openings.

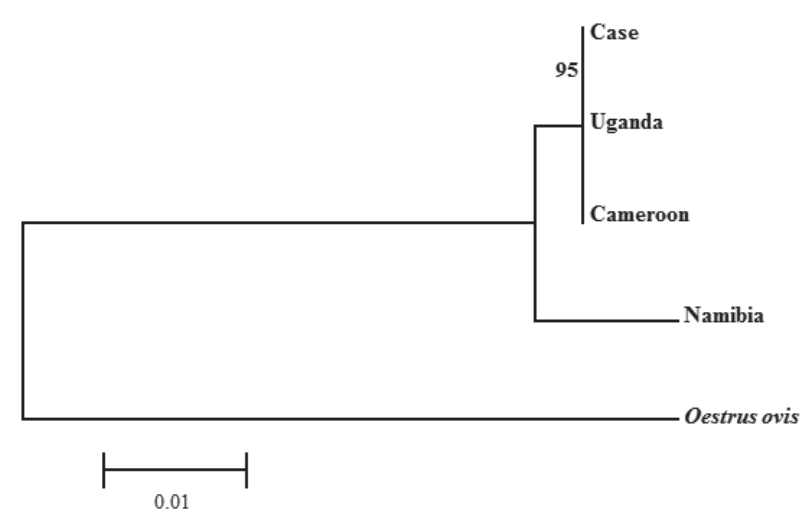

Fig. 5. Phylogenetic tree constructed with the neighbor-joining method using the MEGA 6 program of $C$. anthropophaga based on $28 \mathrm{~S}$ rRNA gene. The distance matrix was calculated by use of Kimura-2 parameters. Numbers on the branches indicated bootstrap proportions with 1,000 replications. vealed that the sequence from this study was clustered with $C$. anthropophaga from Uganda and Cameroon. The 28S rRNA gene sequences of Oestrus ovis (GenBank no. AJ551428) were used as an out-group (Fig. 5).

\section{DISCUSSION}

In Africa, furuncular myiasis is caused by 3 species of the genus Cordylobia: C. anthropophaga (endemic throughout Africa), C. rodhaini (parts of Africa with rainforests), and C. ruandae (Zaire border and Rwanda), whereas D. hominis is common in Central and South America [9]. Among Cordylobia spp., C. anthropophaga is the dominant causative agent compared with the other species [10]. Tamar et al. [4] reported 18 furuncular myiasis cases in Israeli travelers who were returning from Afri- 
ca during 1999-2014. Of these 18 cases, 15 were caused by $C$. anthropophaga, while only 3 were by $C$. rodhaini [4]. They closely resemble each other but can be distinguished by morphological differences, such as the body size, the posterior spiracles, mouth-hooks, and cluster of conic denticles. The length of $C$. anthropophaga is usually $10-15 \mathrm{~mm}$, while $C$. rodhaini is 20-23 mm [11]. In the posterior spiracles, the 3 spiracular openings are slightly sinuous slits in C. anthropophaga, whereas tortuously sinuous in C. rodhaini. C. anthropophaga has mouthhooks with curved and sharp tips, but there is neither cluster of conic denticles nor oral grooves. On the other hand, C. rodhaini has mouth-hooks with broad and rounded tips and cluster of conic denticles as typical feature $[7,12]$.

C. anthropophaga is an obligatory parasite that needs a living tissue of the host for larval development. The female lays 100300 eggs on sandy soil or damp clothing, which has been contaminated with urine or feces. The eggs hatch after 2-4 days, and the hatched larva can survive for up to 9 days without any food. When humans are exposed to contaminated soil or clothing, the larvae penetrate the skin within 60 seconds without any notice. The larva develops into the second instar within 2-4 days, third instar in 5-6 days, and reaches maturity in 8-12 days. Then, the mature larva emerges out of the skin, falls on the ground, and pupates $[1,4]$.

International travel may raise the risk of infectious disease and increase health problems. Up to $8-12 \%$ of travelers with medical problems have skin diseases, of which myiasis is for 7-11\% [13]. Although C. anthropophaga and D. hominis is found in Africa and Central and South Americas, respectively, myiasis is continuously recorded throughout the world due to travelers returning from endemic areas. It has been reported in several countries, including France [9], China [11], US [14], Canada [15], Tunisia [16], Italy [17], Japan [18,19], and Israel [4]. Therefore, sufficient knowledge and experience for diagnosis is needed to avoid misdiagnosis, such as pyoderma, impetigo, staphylococcal furunculosis, and cutaneous leishmaniasis [1]. The diagnosis of myiasis requires awareness of an epidemiological history, recovery of larvae, and morphological study of the larvae. Specifically, key diagnostic features for furuncular myiasis are boil-like lesions, erythema, serosanguineous, or seropurulent drainage from a central punctum, local symptoms of pain, tenderness, and pruritis [3]. Currently, molecular identification methods using several genetic markers, such as mitochondrial DNA and ribosomal DNA, are used to provide more accurate and timely diagnosis [20]. In particular, se- quencing of $28 \mathrm{~S}$ rRNA gene has been used for identification of C. anthropophaga in Japan [18], China [8], and Nigeria [21]. The method of molecular identification which aid to accurate diagnoses of myiasis may be useful for future case studies in hospitals with no expertise. Effective treatment of myiasis is based on the removal of the entire larva after squeezing the boil or applied greasy substance to the lesion and antibiotics therapy to protect any possible secondary infections. Care should be taken as incomplete extraction or rupture of the larva may cause a severe inflammatory response $[2,3]$. The recommended preventive measures against $C$. anthropophaga are drying clothes in sunlight and ironing them before wearing to destroy both the eggs and larvae. It may help reduce the risk of myiasis in endemic areas of $C$. anthropophaga.

This report presents the first case of furuncular myiasis due to $C$. anthropophaga in Korea. However, the increasing number of Korean travelers, both for tourism and business, to tropical and subtropical areas enhances the risk of unusual imported infestations. Considering this point, this report may help to identify the larval species which caused myiasis, to provide the appropriate treatment, and to improve our understandings of imported cases.

\section{CONFLICT OF INTEREST}

We have no conflict of interest related to this study.

\section{REFERENCES}

1. McGraw TA, Turiansky GW. Cutaneous myiasis. J Am Acad Dermatol 2008; 58: 907-926.

2. Robbins K, Khachemoune A. Cutaneous myiasis: a review of the common types of myiasis. Int J Dermatol 2010; 49: 1092-1098.

3. Caissie R, Beaulieu F, Giroux M, Berthod F, Landry PE. Cutaneous myiasis: diagnosis, treatment, and prevention. J Oral Maxillofac Surg 2008; 66: 560-568.

4. Lachish T, Marhoom E, Mumcuoglu KY, Tandlich M, Schwartz E. Myiasis in travelers. J Travel Med 2015; 22: 232-236.

5. Veraldi S, Brusasco A, Süss L. Cutaneous myiasis caused by larvae of Cordylobia anthropophaga (Blanchard). Int J Dermatol 1993; 32: 184-187.

6. Millikan LE. Myiasis. Clin Dermatol 1999; 17: 191-195.

7. Zumpt F. Myiasis in Man and Animals in the Old World. A Textbook for Physicians, Veterinarians and Zoologists. London, UK. Butterworths. 1965, pp 70-77.

8. Ruan W, Feng Y, Zhang L, Sun J, Yao L. Health problems associated with international travel: a case of cutaneous myiasis in China due to Cordylobia anthropophaga imported from Uganda. 
Biosci Trends 2014; 8: 346-349.

9. Dehecq E, Nzungu PN, Cailliez JC, Guevart E, Delhaes L, DeiCas E, Bourel B. Cordylobia anthropophaga (Diptera: Calliphoridae) outside Africa: a case of furuncular myiasis in a child returning from Congo. J Med Entomol 2005; 42: 187-192.

10. Tamir J, Haik J, Schwartz E. Myiasis with lund's fly (Cordylobia rodhaini) in travelers. J Travel Med 2003; 10: 293-295.

11. Deng Y, Liu F, Chen X, Lu S. The first imported cutaneous myiasis due to Cordylobia anthropophaga in China. Int J Dermatol 2013; 52: 120-122.

12. Pezzi M, Cultrera R, Chicca M, Leis M. Scanning electron microscopy investigations of third-instar larva of Cordylobia rodhaini (Diptera: Calliphoridae), an agent of furuncular myiasis. J Med Entomol 2015; 52: 368-374.

13. Villalobos G, Vega-Memije ME, Maravilla P, Martinez-Hernandez F. Myiasis caused by Dermatobia hominis: countries with increased risk for travelers going to neotropic areas. Int J Dermatol. 2016; 55: 1060-1068.

14. Wangia M, Glenn C, Mitchell C, Fisher S. Florid Cordylobia anthropophaga furuncular myiasis from travel in Nigeria. J Dermatol 2012; 39: 1099-1100.

15. MacFadden DR, Waller B, Wizen G, Boggild AK. Imported and locally acquired human myiasis in Canada: a report of two cas- es. CMAJ 2015; 187: 272-275.

16. Kaouech E, Kallel K, Belhadj S, Chaker E. Dermatobia hominis furuncular myiasis in a man returning from Latin America: first imported case in Tunisia. Med Trop (Mars) 2010; 70: 135-136.

17. Calderaro A, Peruzzi S, Gorrini C, Piccolo G, Rossi S, Grignaffini E, Gatti S, Caleffi E, Dettori G, Chezzi C. Myiasis of the scalp due to Dermatobia hominis in a traveler returning from Brazil. Diagn Microbiol Infect Dis 2008; 60: 417-418.

18. Fujisaki R, Makimura K, Hayashi T, Yamamura M, Yamaoka T, Shiraishi K, Ishibashi S, Kawakami S, Kurihara T, Nishiya H. Exotic myiasis caused by 19 larvae of Cordylobia anthropophaga in Namibia and identified using molecular methods in Japan. Trans R Soc Trop Med Hyg 2008; 102: 599-601.

19. Nagamori K, Katayama T, Kumagai M. A case of cutaneous myiasis due to Dermatobia hominis in Japan. J Infect Chemother 2007; 13: 255-257.

20. Otranto D, Stevens JR. Molecular approaches to the study of myiasis-causing larvae. Int J Parasitol 2002; 32: 1345-1360.

21. Ogo NI, Onovoh E, Okubanjo OO, Galindo RC, De la Lastra JM, De la Fuente J. Molecular identification of Cordylobia anthropophaga Blanchard (Diptera: Calliphoridae) larvae collected from dogs (Canis familiaris) in Jos South, Plateau State, Nigeria. Onderstepoort J Vet Res 2012; 79: E1-4. 
